\title{
Impact Of International Agricultural Policies On Rural Poverty In Turkey
}

Bülent Gülçubuk, (E-mail: bulent.gulcubuk@agri.ankara.edu.tr), Ankara University, Turkey Nilay Aluftekin, (E-mail: naluftekin@hotmail.com)Cankaya University, Turkey

\begin{abstract}
Poverty is one of the important subjects that come into question in the world in the last decade. Poverty affects people directly or indirectly. Poverty begins to constitute most important problem of community and economic life in Turkey. Because of development in economy, fluctuations, shocks and commitments to international agriculture politics (World Bank, WTO, IMF practices) and politics that put into practice after 1980's have effected and continue to effect agriculture sector in Turkey. From now on, agricultural politics are determined by international organizations and companies. Politics that are put in practice for agriculture, price interventions, changes in support politics, privatization, reduce in input supports, to open out to international markets have mostly influenced small agricultural enterprises and landless.
\end{abstract}

According to results of General Agriculture Census (2001), there are 3.020 .000 agricultural enterprises in Turkey and $83 \%$ of them are smaller than 10 hectares. In addition to this, $30 \%$ of agricultural population consists from landless. The most effected parts are landless and small agricultural enterprises because of practices such as sugar law, tobacco law, and change in support politics that result in international agricultural politics. This process brings about gradually increase and deepen in poverty in rural area with migration, unemployment and income distribution problems at national level.

International agricultural politics mostly affect sugar and tobacco producers because of sugar and tobacco are the most important agricultural products in Turkey. Nearly 1 million sugar and tobacco producer families and 4.5-5.0 million people employ in transportation, marketing, and processing of these products. Because of sugar and tobacco law and limitations in producing hazelnut and tea plant, nearly 1.5 million producer families and labors who are involved in related sectors have directly affected.

According to Household Budget Questionnaire in 2002, 38\% of total population of Turkey is living with 2 USA Dollar income. At this point, it is so important to state that, rural areas feel poverty more deeply than urban areas. In fact, poverty ratio is $43 \%$ in rural areas that means of subsistence is only agriculture. In addition to this, the rate of absolute poverty in rural areas is 3,5 times of urban areas.

In this paper, definition and characteristics of poverty and rural poverty in Turkey will be dealt with and effects of international politics on rural poverty will be examined.

\section{INTRODUCTION}

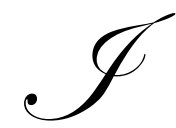

n Turkey, agriculture is among those sectors most affected by recent processes known as globalization, more liberalization and "opening outward." Liberalized foreign trade of agricultural products, international agreements, and privatization affect millions of people directly. Agricultural policies shaped by the World Bank, World Trade Organization, European Union and the foreign policies of the US affect small farmers and landless rural population, which accounts for $30 \%$ of total rural population, and force them into poverty, 
unemployment, migration to urban centers and work without any protection. An all these stages, deepening poverty in the rural sector generate serious country-wide problems. In developing countries like Turkey, poverty does not emerge only as some kind of economic insufficiency. It also brings pressure on natural environment, affects social dynamics and accelerates cultural and political marginalization.

Defined as the lack of goods and services to meet the physical and human needs of people, poverty affects rural people more. This is because a significant part of rural people consists of small farmers and landless peasants. These people merely try to subsist on the least. Rural people feel poverty deeper since they can hardly benefit from basic social rights and services. Economic policies adopted after the 80 s particularly affect small farmers, landless peasants and other who are engaged in subsistence stockbreeding of small ruminants. These people mostly concentrate in the less developed or backward regions of the country and their alternative sources of income are extremely limited. They also constitute the most dispersed and unorganized group in the rural sector. The process of economic and social change pushes this group deeper and deeper in poverty.

\section{RURAL POPULATION AND AGRICULTURAL EMPLOYMENT IN TURKEY}

In spite of policies that placed weight on industry especially since the 70 s, the sector of agriculture still maintains its importance in terms of employment. It is not an easy task to exactly assess the level of importance of agriculture in economy. Although there are statistical data giving information about the place of agriculture in Turkish economy, there is yet no single measure to assess its place in overall socio-economic life. Nevertheless it is an established approach to assess the status of agriculture by referring to such indicators as national income, population share, actively employed population and contribution to foreign trade and industry. The most important among these is employment. Indeed, with its share in foreign trade and national income declining down to $10 \%$, agriculture still provides employment to about $40 \%$ of population.

\section{Agricultural Population And Share Of Agriculture In Employment}

The share of rural population in total population is gradually declining as a result of economic growth and rapid urbanization. While the share of rural population (villages and townships) was $56.1 \%$ in 1980 , it first fell to 41 $\%$ in 1990 and further to $35.1 \%$ in 2000 (Table.1). This share, of course, is still high compared to developed countries. However, considering that these countries had their agriculture developed together with industry and that urbanization followed a planned path, it becomes obvious that urbanization, rural-to-urban population shift and declining rural population in Turkey are all outcomes of forcing and pushing factors rather than a balanced development process. Population censuses in Turkey give total population segregated by rural and urban settlement. Since the main economic activities in villages and townships are of agricultural nature, people living in these settlements are generally categorized as "agricultural population."

Table 1. Rural Population Trends in Turkey

\begin{tabular}{|c|c|c|c|c|c|c|}
\hline Census Years & $\begin{array}{c}\text { Total Rural } \\
\text { Population } \\
\text { (Villages and } \\
\text { townships) }\end{array}$ & $\begin{array}{c}\text { Share of Rural } \\
\text { Pop. (\%) }\end{array}$ & $\begin{array}{c}\text { Urban } \\
\text { Population }\end{array}$ & $\begin{array}{c}\text { Share of Urban } \\
\text { Pop. (\%) }\end{array}$ & $\begin{array}{c}\text { Total } \\
\text { Population }\end{array}$ & $\begin{array}{c}\text { Rate of Pop. } \\
\text { Growth (\%) }\end{array}$ \\
\hline 1980 & 25.091 .950 & 56,1 & 19.645 .007 & 43,9 & 44.736 .957 & 2,07 \\
\hline 1985 & 23.798 .701 & 47,0 & 26.865 .757 & 53,0 & 50.664 .458 & 2,49 \\
\hline 1990 & 23.146 .684 & 41,0 & 33.326 .351 & 59,0 & 56.473 .035 & 2,17 \\
\hline 2000 & 23.797 .653 & 35,1 & 44.006 .274 & 64,9 & 67.803 .927 & 1,83 \\
\hline
\end{tabular}

Source: SIS, General Censuses.

As seen in Table 1 above, agricultural (rural) population relatively declined until 1985 and this decline continued in absolute terms until 1997-2000 when there was a considerable increase in absolute terms. In spite of this fall there are still 23.8 million people living in rural areas. The most important fact in the table is the increase in 
rural population by 650,000 , whatever the reason may be. At present, agriculture is the largest employment generating sector in Turkey. In 2003, agriculture accounted for $33.9 \%$ of total employment in the country.

Table 2. Employment by Sectors (000 persons over age 12)

\begin{tabular}{|c|c|c|c|c|c|c|c|c|}
\hline \multirow{3}{*}{ Years } & \multicolumn{6}{|c|}{ Sectors } & \multirow{2}{*}{\multicolumn{2}{|c|}{ Total }} \\
\hline & \multicolumn{2}{|c|}{ Agriculture } & \multicolumn{2}{|c|}{ Industry } & \multicolumn{2}{|c|}{ Services } & & \\
\hline & Number & $\%$ & Number & $\%$ & Number & $\%$ & Number & $\%$ \\
\hline 1990 & 9.355 & 46,9 & 4.274 & 21,4 & 6.317 & 31,7 & 19.946 & 100,0 \\
\hline 1995 & 10.226 & 47,8 & 4.417 & 20,7 & 6.734 & 31,5 & 21.378 & 100,0 \\
\hline 1999 & 8.839 & 40,8 & 5.087 & 23,5 & 7.717 & 35,7 & 21.643 & 100,0 \\
\hline $2000\left(^{*}\right)$ & 7.103 & 34,5 & 3738 & 18,2 & 9738 & 47,3 & 20.579 & 100,0 \\
\hline $2001(*)$ & 7.217 & 35,4 & 3734 & 18,3 & 9415 & 46,3 & 20.367 & $\overline{100,0}$ \\
\hline 2003 & 7.165 & 33,9 & 3769 & 18,1 & $10135 * *$ & 48,0 & 21.147 & 100,0 \\
\hline
\end{tabular}

Source: SIS, Household Labor Force Surveys.

*: In these years, population over age 15 is considered in employment by sectors.

**: This includes 965,000 construction workers.

As can be seen in Table 2, fall in the employment share of agriculture is slower than the fall in the share of agricultural population in total. Besides its statistically confirmed position in total employment, there are hundreds of thousands of others working informally and not appearing in censuses and surveys. In total agricultural employment, the shares of unpaid domestic labor and self-employed/employers are, respectively, $50.9 \%$ and $43.7 \%$. In nonagricultural activities, on the other hand, corresponding shares are $73.8 \%$ and $22.7 \%$ (Table.3). This points out to low labor returns in agriculture.

Table 3. Wage Work in the Sector of Agriculture

\begin{tabular}{|l|c|c|}
\hline \multirow{2}{*}{ Working Status } & \multicolumn{2}{|c|}{$\mathbf{2 0 0 3}$} \\
\cline { 2 - 3 } & Persons ( 000) & $\mathbf{3 3 , 9}$ \\
\hline 1) Agriculture, Forestry, Fishing & $\mathbf{7 . 1 6 5}$ & 1,9 \\
\hline -Wage earner & 389 & 14,8 \\
\hline - Self employed - employer & 3.130 & 17,2 \\
\hline - Unpaid domestic worker & 3.646 & $\mathbf{6 6 , 1}$ \\
\hline 2) Non-agricultural activities & $\mathbf{1 3 . 9 8 2}$ & 48,8 \\
\hline - Wage earner & 10.319 & 15,0 \\
\hline - Self employed - employer & 3.171 & 2,3 \\
\hline - Unpaid domestic worker & 492 & $\mathbf{1 0 0 , 0}$ \\
\hline 3) Total (1+2) & $\mathbf{2 1 . 1 4 7}$ & \\
\hline
\end{tabular}

Source: SIS, Household Labor Force Survey-Provisional Results-2003.

\section{Agricultural Works And Labor Use In Turkey}

According to the provisional results of 2003 Household Labor Force Survey (SIS-State Institute of Statistics) $33.9 \%$ of active population are employed in agriculture. Considering that children under age 12 are also employed in this sector, it is possible to say that in Turkey there are about 10-12 million people working in agriculture. Looking at the distribution of employment by sectors, we see that agriculture still maintains its importance. The shares of other sectors are $18.1 \%$ (industry) and services (including construction) (48\%). As can be seen in Table.4 the total labor force participation ratio is $48.3 \%, 70.4 \%$ in males and 26.65 in females. Corresponding figures for the rural sector are $55.5 \%$ (total), $72.9 \%$ (males) and $39 \%$ (females). Further, $69.4 \%$ of rural employment consists of agricultural activities (55.5\% for males and $89.1 \%$ for females). That is, agricultural activities account for almost all rural female employment. 
Table 4. Labor Force Participation ratios in Turkey (\%)

\begin{tabular}{|c|c|c|c|}
\hline Participating & $\begin{array}{c}\text { Participation ratio } \\
\text { by Total Population }\end{array}$ & $\begin{array}{c}\text { Participation ratio } \\
\text { in Rural Areas }\end{array}$ & $\begin{array}{c}\text { Share of Agriculture in Rural } \\
\text { Employment }\end{array}$ \\
\hline Total population & 48,3 & 55,5 & 69,4 \\
\hline Male & 70,4 & 72,9 & 55,5 \\
\hline Female & 26,6 & 39,0 & 89,1 \\
\hline
\end{tabular}

Source: SIS, Household Labor Force Survey-Provisional Results-2003.

Females in agriculture are predominantly unpaid domestic workers working in small family enterprises. As a part of domestic labor, women either directly take part in activities of the family enterprise or work for wage in other enterprises where they deliver their earnings to their husbands as the head of the household.

Looking at the remuneration status of women (Table.5), we see that $81.4 \%$ are unpaid domestic workers, $15.9 \%$ are either self-employed or employer and 2.45 are wage earners. Hence, while there is considerable number of women actively working in agriculture only a small portion is real wage earners. Overwhelming part of their work consists of what is expected from them in their traditional roles and duties. It should be noted that these data include no official statistics about migrant agricultural workers.

Table 5. Distribution of People Working in Agriculture by their Payment Status (\%)

\begin{tabular}{|c|c|c|c|}
\hline Status & $\begin{array}{c}\text { Total Population } \\
\text { in Agriculture }\end{array}$ & Male & Female \\
\hline Unpaid domestic worker & 50,9 & 25,1 & 81,4 \\
\hline Self employed or employer & 43,7 & 68,8 & 15,9 \\
\hline Wage and salary earners & 5,4 & 6,1 & 2,7 \\
\hline Total & $\mathbf{1 0 0 , 0}$ & $\mathbf{1 0 0 , 0}$ & $\mathbf{1 0 0 , 0}$ \\
\hline
\end{tabular}

Source: SIS, Household Labor Force Survey-Provisional Results-2003.

\section{THE CONCEPT OF POVERTY IN ITS UNIVERSAL DIMENSION}

There is no commonly agreed definition of poverty. This is natural since both poverty and wealth are basically subjective concepts. The concept of poverty starts out from basic human needs. Hence, basic indicators include nutrition, clothing, housing, education, health, etc. According to the World Bank Poverty is a state in which minimum standards of living are not achieved (World Bank, 1990). In general, definitions of poverty refer to the following: economic insufficiency, physical incapability, low level of participation, environmental pollution, imbalanced income and property distribution, political instability, inefficiency of public services and lack of social security.

According to a definition which is received well by both academic and political circles, poverty can be defined in two forms (IFAD, 2001):

- $\quad$ Absolute poverty: Here a person merely subsists at minimum level. In other words a person in absolute poverty can find just enough calories and other nutrients to survive biologically. Those with cash or in-kind income insufficient to provide for these basic needs are considered as under absolute poverty line.

- $\quad$ Relative poverty: This refers to a level of consumption and living which is necessary not for biological but social survival and reproduction. Hence, in a given society, those earning under an acceptable minimum consumption level are considered relatively poor.

These two concepts are given functionality mostly in terms of monetary indicators. For example, international comparisons on absolute poverty are based on the measure of a daily spending of 1 US dollar at purchasing power parity. 
The measure for relative poverty, on the other hand, is the proportion to total population of those who are at an income level that is some percentage (i.e. $40 \%$ ) lower than the average or median income level for a given country. But, there are some problems associated with defining poverty merely as low income level or a figure deviating from the mean/median figure. It is widely accepted recently that a measure focusing solely on income would fail to give information on other important indicators such as exercise of and/or accessibility to some rights and opportunities available in the context of a given society.

Taking account of these, poverty is defined in two distinct forms in regard to its content. In its narrower sense poverty refers to a situation in which an individual has food, clothing and shelter just enough for survival. Wider definition, on the other, takes poverty as a state where individuals can provide for their needs only at a level which is below what the society has in general.

\section{GENERAL PROFILE OF POVERTY IN THE RURAL SECTOR}

Poverty has become a sociological reality in Turkey, which can no more be neglected or discarded. According to 2002 Household Budget Survey of the SIS, thee poorest $20 \%$ of households or 12.2 million people making up $17.8 \%$ of total population earn 1 US dollar a day. The second quintile covering 13.5 million people, making up $19.8 \%$ of total population live on a daily income of 2 dollars. Under international standards, daily income of 1 dollar denotes the "line of hunger" whereas 2 dollars stand for the poverty line. Accordingly, there are 12 million people in Turkey living around hunger line and the total number of poor reaches 25.7 million corresponding to 37.65 of total population.

Table 6. Distribution of Annual Disposable Household Income by Percentile Groups of $20 \%$

\begin{tabular}{|c|c|c|c|}
\hline Groups & Turkey & Urban & Rural \\
\hline First 20\% & 5,3 & 5,5 & 5,2 \\
\hline Second 20\% & 9,8 & 9,7 & 10,3 \\
\hline Third 20\% & 14,0 & 13,9 & 14,7 \\
\hline Fourth 20\% & 20,8 & 20,5 & 21,7 \\
\hline Fifth 20\% & 50,1 & 50,4 & 48,0 \\
\hline TOTAL & $\mathbf{1 0 0 , 0}$ & $\mathbf{1 0 0 , 0}$ & $\mathbf{1 0 0 , 0}$ \\
\hline
\end{tabular}

Source: SIS, 2002. (www.die.gov.tr)

Table.6 above divides some 16.5 million families in Turkey into five income groups according to the findings of the 2002 SIS Household Budget Survey. According to this table, families making up the fifth quintile have income levels 10 times higher than of those in the first quintile.

Table 7. Local and Regional Rates of Poverty

\begin{tabular}{|c|c|c|c|c|}
\hline $\begin{array}{c}\text { Settlement Types } \\
\text { and Regions }\end{array}$ & Absolute Poverty & Relative Poverty & Middle & Upper \\
\hline Urban & 2,8 & 21,8 & 39,0 & 36,4 \\
\hline Rural & 9,3 & 33,0 & 36,7 & 21,0 \\
\hline Region & & & & \\
\hline Marmara & 1,3 & 18,3 & 40,5 & 39,9 \\
\hline Aegean & 2,6 & 22,4 & 46,7 & 28,2 \\
\hline Mediterranean & 7,7 & 29,5 & 37,1 & 25,7 \\
\hline Central Anatolia & 6,0 & 28,1 & 36,3 & 29,6 \\
\hline Black Sea & 8,1 & 31,0 & 36,3 & 24,6 \\
\hline Eastern Anatolia & 7,7 & 32,0 & 32,3 & 28,0 \\
\hline Southeastern Anatolia & 17,5 & 45,2 & 24,3 & 13,0 \\
\hline
\end{tabular}

Source: SIS, 2002. (www.die.gov.tr) 
Examining Table. 2 we observe that the rate of absolute poverty is 3.5 times higher in rural areas than in urban and relative poverty is again higher by 1.5 times. Accordingly, the people suffering a daily income of 1 dollar are much more numerous in rural areas. In regional terms, rates of absolute and relative poverty are higher in the regions of Black Sea, Eastern Anatolia, and Southeastern Anatolia. Thus, it is obvious that poverty alleviation policies must first focus on rural areas and agricultural policies.

One of the most common approaches to assess poverty is the calculation method based on minimum level of food expenditures. A study made by using this approach (Erdoğan, 1997) draws the picture of poverty in Turkey as outlined in the following table.

Table 8.Poverty Rate by Minimum Per Capita Food Expenditure

\begin{tabular}{|c|c|}
\hline Settlement Types and Regions & Rate of the poor (\%) \\
\hline TURKEY & 15 \\
\hline Urban & $\mathbf{1 0}$ \\
\hline Rural & $\mathbf{2 1}$ \\
\hline Marmara & 7 \\
\hline Aegean & 4 \\
\hline Mediterranean & 11 \\
\hline Central Anatolia & 12 \\
\hline Black Sea & 19 \\
\hline Eastern Anatolia & 25 \\
\hline Southeastern Anatolia & 24 \\
\hline
\end{tabular}

As can be seen in Table. 8 the rate of poverty in the rural sector is double of that in urban areas. According to the SIS figures, the total rate of poverty which was $12.2 \%$ in 1987 rose to 21.3 in 1994 . In the same period, while the rate of urban poverty rose from $9.3 \%$ to $12.4 \%$, the increase was from $18.7 \%$ to $26.9 \%$ in rural areas. It should be noted here that faster rate of increase in urban areas derives mainly from rural-to-urban migration. The most recent study on poverty in Turkey is based on data relevant for 2002. According to data published in the Economic Bulletin of Anka Agency, there are 14 million people in Turkey trying to subsist by spending at most 1 dollar a day and one person out of five is under the line of hunger. According to the same study, while the first quintile (the poorest) is on the boundary of 1 dollar of spending a day, the boundary for the second quintile (relatively poor) is 1.8 dollars (Uras, 2003). All these point out that poverty is further deepening in Turkey. Poverty is more pronounced in rural areas where income sources and occupational diversity are both more limited. The International Labor Organization (ILO) defines rural poverty as open or disguised unemployment in the sector and draws attention to the process of rapid rural pauperization along with steadily falling levels of income. Indeed, recent policies deeply affect people living in rural areas. The phenomenon of poverty has particularly deep impacts on small farmers, agricultural workers, tenants and sharecroppers, shepherds and those engaged in small head animal husbandry.

General trends in the economy suggest that the sector of agriculture will maintain its importance in the socioeconomic life of the country for some time. In the face of the fact that the sector of industry confronts problems in enlarging its employment capacity, solution to the problem of employment will be sought, at least to a certain extent, once again in the sector of agriculture. The latest General Agriculture Census and Population Census points out to some interesting facts. According to the General Population Census of 2000, there is an absolute increase of 700,000 people in rural population (compared to 1990). On the other hand, the Agricultural Census of 2001 shows that there has been $23.8 \%$ decrease in the number of agricultural enterprises and $21.4 \%$ shrinking of land under culture (compared to 1991). This means, there are significant decreases in both the number of agricultural enterprises and land under culture while there is a slight increase in rural population. This can be interpreted as further rise of poverty in the rural sector. 


\section{INTERNATIONAL AGRICULTURAL POLICIES - TURKISH AGRICULTURE AND POVERTY}

Economic crises/shocks experienced especially after the 90s, further dominancy of international policies in agriculture and domestic policies on stockbreeding have all led to significant changes in the rural sector. In this period, rural-to-urban migration accelerated, urban unemployment increased and small farmers as well as landless peasants were driven out of self-sufficiency. The number of people suffering absolute poverty is increasing over years in Turkey. Such factors as distorted income distribution, macroeconomic fluctuations, and irrational utilization of resources lead to increase in the number of those living in relative poverty in particular. The policies of the last 1015 years left agriculture and rural population in a rather difficult position.

Whatever their level of development may be, agriculture has its unique place and importance in the economy of all countries. In a country like Turkey where almost $40 \%$ of population is employed in agriculture, this sector is still the major one in terms of national income, exports and food security. Nevertheless it is not an easy task to exactly gauge the role of agriculture in the economy of a country. Though statistical data may yield some information about agriculture's contribution to national economy, there is still no single and agreed measure to assess its place in socioeconomic life. Yet, it is a widely accepted approach to asses the position of agriculture in national economy by focusing on such parameters as national income, total and active population and contribution to foreign trade.

It is clear that agricultural policies adopted in Turkey triggered the emergence of some important problems in the sector. Policies designed to adjust to changing international conditions brought along by liberalization fail, in many cases, to ensure the structural change that the country needs and, to the contrary, lead to new socioeconomic problems that place millions of people in agriculture in a more difficult situation. Recent policies in agriculture have been shaped not by national priorities but by some international tendencies and preferences. In Turkish agriculture, food trade in particular will be affected by international developments mutually consolidating each other. Specific examples include the Customs Union (CU) the Agreement on Agriculture of the World Trade Organization. One can assign more importance to the $\mathrm{CU}$ in Turkey's process of accession to the EU; however, all agreements of this nature are indeed supplementary to each other. With the $\mathrm{CU}$, which aims to create a more liberalized trade environment, the process of liberalization is shaped not by the concerns of developing countries but more by the desire of industrialized countries to further consolidate their competitive power in foreign trade.

In Turkey, the sub-sectors of sugar and tobacco are more deeply affected by prevailing international policies. These two are the leading agricultural products of Turkey. Sugar (including sugar beet culture) and tobacco subsectors cover about 1 million growers and further employ 4.5-5 million people engaged in transportation, marketing and processing stages. However, the new legislation on sugar and tobacco as well as limiting quotas placed on hazel nut and tea directly affected about 1.5 million growers and further millions of people engaged in works related to these products. Indeed, the Sugar Code dated 04.04.2001 and the Tobacco Code dated 20.06.2001 had their immediate consequences in that both area under the culture of relevant crops and their total output rapidly shrunk. For example, while area under sugar beet culture was 423,393 hectares in 2000, it fell to 359,000 hectares in 2003. Within the same period, the number of sugar beet growers decreased from 500,000 to 410,000. A similar trend is observed in tobacco. Output decreased from 216,000 tons in 2000 to 149,846 tons in 2003. Also, the number of tobacco growers dropped from 586,616 to 334,176 . While being effective indeed in this regard, the policies of globalization, however, introduced no measures to the benefit of millions of people losing their basic means of subsistence. Poverty is, then, a natural outcome.

\section{WTO Geneva Framework Agreement - 1 August 2004}

The World Trade Organization (WTO) is high up in world's agenda with its decisions and actions affecting the lives and daily labor of so any people. The WTO is an international organization striving to establish a specific trade concept and its practices pertinent to a world with no national boundaries and therefore customs. On paper, the WTO's aim is to create a world where globalization is fully established and where nobody treats someone else as "the other." The essential solution to all problems, according to the WTO, is competition freed from all constraints, limitations, and protective shields. 
However, agriculture still stands as one of the most problematic areas for the WTO. Targeting fully liberalized world agriculture, the WTO is at pains in making its agriculture related decisions operational in market conditions. As a matter of fact, the WTO meting in Daho in 2001 had to be postponed to 2003 upon failure to reach a consensus on agriculture related issues. The WTO gathered again in Mexico in 2003, again without reaching a conclusion. Finally the decisions of the WTO dated 1 August 2004 are of close interest to many countries including Turkey. This last meeting ended up with a framework agreement to "bring agricultural trade in line with free market dynamics." This framework will be filled in by the outcomes of a new meeting to be held in Hong Kong in September 2005.

\section{The Geneva Framework Agreement Essentially Aims At Introducing New Arrangements In Three Areas:}

1. Lowering of customs duties: Countries are required to lower customs duties applied on agricultural products imported from abroad. This means that the WTO requires developing and underdeveloped countries to open their boundaries and customs to importation of agricultural products. This is the essence of the Geneva Agreement. The details and procedures related to this arrangement will be set later in September 2005 at the meeting to be held in Hong Kong. The most important point to be noted here is the restarting of the process of abolishing all kinds of support to agriculture and letting trade in agricultural goods take place in market conditions without and support or protection. Tariffs, domestic support, and incentives for exports will be gradually abandoned. "Productivity" and "competition" will be the key words of the new process. This is of utmost importance for countries like Turkey where small enterprises dominate agriculture and where both transition to purely market oriented farming and shifting from one crop to another is quite difficult.

2. Lowering of State subsidies to agricultural production: The State is ultimately expected to extend no support at all to farmers. Such a process will inevitably prove small enterprises, now deprived of input subsidies, more and more uncompetitive.

3. Lowering of State subsidies to exportation: All countries are expected to minimize their support to farmers and exporters of agricultural products. However, the pressure of developed countries to obtain exceptions for some of their products and attempts to maintain their support in more roundabout ways may end up in an international competition contrary to what is declared as the goal.

\section{The Following Remarks Can Be Made Concerning These Decisions:}

The first two decision given above will enable the US, EU and Canada to gain full control of the world market in agricultural goods. Since these countries can produce much cheaper than others, their products may well dominate world markets. This means the further liberalization of agriculture for developed countries. As far as Turkey is concerned, any lowering in this sense will have its direct bearing on the sector. In this last meeting Turkey presented the WTO a list of "critical crops/products" which included 20 items. 13-14 of these are meat products, and some crops like pulses and rice also appear in the list. But the list was returned to Turkey on the ground that it was "too long." It is clear that countries that can produce much cheaper thanks to their advanced technologies will sell their products to countries like Turkey, which can only produce at high cost. This is expected to start in 2006.

The rhetoric used here needs closer attention. Developing countries are told that they can produce and sell more if tariffs are lifted and supportive policies are abandoned. It is quite doubtful that this will actually happen. Taking the case of Turkey as an example, farmers will no more be given subsidized credit and input opportunities, areas under culture will be limited, there will be no more price support policies and export incentives. This leaves out only direct income support, which will cease soon and which goes only to landowner anyway. Is this picture promising for Turkey in terms of grabbing above-mentioned "opportunities"? To the contrary all these point out to a more severe and intensive process of rural pauperization and agricultural collapse. Without any support or subsidy, especially small farmers and others who cannot possibly find alternative means of subsistence and income generation will be rapidly pushed in the cycle of poverty. 
The Geneva decisions may have devastating effects on Turkish agriculture, especially in relation to such products as sugar beet (and sugar industry), tobacco, cotton and tea. Another sector that will be deeply affected is animal husbandry. At present, the highest import tariffs in Turkey are applied to meat products from cattle, sheep and goat $(227.5 \%)$. The rate is $65 \%$ for poultry products. These high tariff "walls" are indeed contrary to the WTO rules and the WTO may well resort to sanctions. In such a case, Turkey may have to lift protection in animal products as well. This will be the sign of a new phase that places pressures on Turkey's imports and exports. Turkey, for example, may have to lower $180 \%$ high import tariffs in such crops as wheat. In animal products Turkey may well be dependent to such countries as the US, Canada, the Netherlands, and Great Britain.

\section{CONCLUSION-APPROACHES FOR SOLUTION}

Turkey is losing her self-sufficiency in agriculture especially as a result of the policies of the last 10-15 years. The country is gradually becoming import dependent in some agricultural products. A significant part of the population face problems related to malnutrition. Rural poverty is gaining further dimensions and the rural poor feel the negative impact of agricultural policies more deeply. Agricultural incomes are falling. Agricultural policies in Turkey are now shaped more by the approaches of international organizations and companies. All these brings along an environment of uncertainty. Yet, social and economic development in the rural sector, extension of all modern services of the civilized world to rural areas as well and shaping of agricultural policies on the basis of economic and social realities of the sector are still important issues. This is critical since if the present policies prove to be unsuccessful the emerging cost will be too high to remedy for. As a matter of fact, the point that unemployment and poverty have presently reached places these two issues at the top of the agenda in designing national policies.

Poverty is indeed a deepening problem in Turkey. It is now approaching the hunger line in many respects. In its socioeconomic dimensions and consequences, poverty is the problem of the society as a whole, not only those who suffer it directly. Poverty feeds economic failure, physical insufficiency, environmental degradation, unbalanced income distribution, and further marginalization. Regardless of its causes, nature and dimensions, the common feature of poverty is its sociological and psychological effects on society. At present, if 14 million people in Turkey have to live on 1 US dollar a day, this well lead to much graver problems in future. All these make it imperative to develop accessible and feasible methods of fighting against poverty:

Basing on what have been said so far, what follows are some approaches for the solution of the problem of rural poverty:

- $\quad$ Costs in agricultural sector may be pulled down by organizing small farmers.

- $\quad$ Farmers may be assisted in their market access through their own organizations.

- Agro or rural industries may be introduced and developed at local level. Areas promising for local entrepreneurship may be determined taking account of national and regional needs and priorities.

- $\quad$ New income and business opportunities may be created by placing emphasis on such lines as agro-rural tourism, which doe snot require any heavy initial investment and property.

- A comprehensive policy for the reduction of rural poverty may reveal existing potentials and weaknesses, on which relevant strategies will be based.

- $\quad$ Rural development policies based on national priorities may be designed.

- $\quad$ Public and non-public organizational structures may be introduced to determine policies and strategies on poverty alleviation.

- $\quad$ An effective and accessible social security system covering all individuals may be introduced.

- $\quad$ Periodic researches may be conducted to disclose the dimensions of poverty. These researches will lay the ground for poverty mapping and regional-local initiatives.

- $\quad$ Effectiveness of existing assistance schemes may be assessed.

- $\quad$ Participation of the poor to decision making processes may be enhanced.

- $\quad$ Efforts may be made to mitigate the negative impacts of international agricultural policies by enhancing the value added and employment potential of the sector of industry. According to data relevant for 2002, agriculture accounts for $33.5 \%$ of total employment in Turkey (the share of industry is $19 \%$ ). 
Finally, suggestions developed by the UNDP for the elimination of the problem of poverty are also relevant for Turkey. These suggestions include the extension of basic social services, agrarian reform, provision of credit accessible to all, employment, social security network, participation, reaching disadvantage sections and sustainability.

\section{BIBLIOGRAPHY}

1. Çevre Bakanlığı-UNDP, 2002. Sürdürülebilir Kalkınma Ulusal Raporu. Çevre Bakanlığı-UNDP Yayını, Ankara

2. DİE.,1980-2001. Tarımsal Yapı ve Üretim İstatistikleri. Başbakanlık DİE Yayınları, Ankara.

3. DİE., 1991. Genel Tarım Sayımı. Başbakanlık DİE Yayınları, Yayın No:1691, Ankara.

4. $\quad$ DİE.,2002. Hane Halkı Bütçe Anketi Sonuçları. DİE Yayınları, Ankara.

5. DPT.,2000. Sekizinci Beş Yıllık Kalkınma Planı 2001-2005. Başbakanlık-DPT,Ankara.

6. Erdoğan,G., 1997. Türkiye'de Yoksulluk: Boyutu ve Profili. Başbakanlık DİE Yayınları,Ankara.

7. Gülçubuk.B., 2002. Küreselleşmenin Kavramsal Çerçevesi Temel Dinamikleri ve Türkiye. Türkiye V. Tarım Ekonomisi Kongresi, 18-20 Eylül 2002,Erzurum, s.26-33.

8. Gülçubuk,B., "Globalization and The Agricultural Labor Market in Türkiye". The 6 th Conference of The European Soc. Association, 23-26 September 2003, Spain.

9. Günaydın, Gökhan., 2001. Küreselleşme ve Türkiye Tarımı. TMMOB-ZMO Yayınları, Tarım Politikaları Yayın Dizisi No:3, s.20-27,Ankara.

10. Güneş,E.-Albayrak,M.-Gülçubuk,B., 2002. Türkiye'de Gıda Sanayii. Tekgıda-İ̧ş Sendikası Yayınları, Ankara.

11. Gürbüz.,M. 2004. WTO Cenevre Tarım Çerçevesine İlişkin TEMA Vakfı Değerlendirmesi.

12. Hart, Michael., 1997. "The WTO and the Political Economy of Globalization". Journal of World Trade. XXXI-USA.

13. IFAD., 2001. Rural Poverty Report 2001: The Challenge of Ending Rural Poverty, IFAD-USA.

14. İKV., 2000b.Gümrük Birliği’nin Türkiye Ekonomisine Etkileri (İlk Dört Yılın Ekonometrik Analizi) İKV Yayınları, No: 159, s.6,İstanbul.

15. Korten, David C., 1996.The Failures of Bretton Woods.San Francisco:SierraClubBooks-USA.

16. OECD., 2000. A New Economy?, The Changing role of Innovation and Information Technology in Growth, Information Century., OECD-USA.

17. SETBİR., 1997. AB ve GATT Karşısında Türk Gıda Sektörü. SET-BİR Yayınları,İstanbul.

18. Uras,G., 2003. “14 Milyon Türk Günde 1 Dolar Harcayarak Yaşıyor.” Milliyet Gazetesi-17.10.2003.

19. Woods, Ngaire., 2000.The Political Economy of Globalization. St. Martin’s Press, NY-USA.

20. World Bank., 1990. World Development Report. World Bank-USA.

21. World Bank., 2001. World Development Report 2000/2001, World Bank-Oxford: Oxford University Press,USA. 